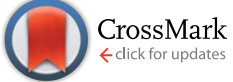

Cite this: RSC Adv., 2015, 5, 11212

\title{
Improved performance of lipases immobilized on heterofunctional octyl-glyoxyl agarose beads $\uparrow$
}

\author{
Nazzoly Rueda, ${ }^{\text {ab }}$ Jose C. S. dos Santos, ${ }^{\text {ac }}$ Rodrigo Torres, $\dot{t}^{\mathrm{b}}$ Claudia Ortiz, ${ }^{\mathrm{d}}$ \\ Oveimar Barbosa*e and Roberto Fernandez-Lafuente*a
}

A new heterofunctional support, octyl-glyoxyl agarose, is proposed in this study. The supports were prepared by simple periodate oxidation of the commercial octyl-agarose, introducing $25 \mu \mathrm{mol}$ of glyoxyl groups per wet gram of support. This support was assayed with three different lipases (those from Candida antarctica (form B), Thermomyces lanuginosus (TLL) or Rhizomucor miehei) and the artificial phospholipase Lecitase Ultra. Used at $\mathrm{pH}$ 7, the new support maintained as first immobilization step the lipase interfacial activation. Thus, it was possible to have the purification and immobilization of the enzyme in one step. Moreover, stabilization of the open form of the lipase was achieved. The covalent enzyme/support bonds cannot be obtained if the immobilized enzyme was not incubated at alkaline $\mathrm{pH}$ value. This incubation at $\mathrm{pH} 10$ of the previously immobilized enzymes produced a smaller decrease in enzyme activity when compared to the direct immobilization of the enzymes on glyoxyl-agarose at $\mathrm{pH}$ 10 , because the immobilization via interfacial activation promoted a stabilization of the lipases. Except in the case of TLL (covalent attachment involved $70 \%$ of the enzyme molecules), covalent immobilization yield was over $80 \%$. The non-covalent attached enzyme molecules were discarded by washings with detergent solutions and the new biocatalysts were compared to the octyl-agarose immobilized enzymes. While the stability in thermal and organic solvents inactivations was increased for Lecitase Ultra, CALB and RML, TLL improved its stability in organic media but its thermal stability decreased after covalent attachment of the interfacially activated enzyme. This stabilization resulted in octyl-glyoxyllipase preparations which presented higher activity in the presence of organic solvents. Finally, while octyl-agarose released enzyme molecules after incubation at high temperatures or in the presence of organic solvents and detergents, the covalently immobilized enzyme remained attached to the support even after boiling the enzyme in SDS, eliminating the risks of product contamination.

Received 28th October 2014 Accepted 7th January 2015

DOI: 10.1039/c4ra13338b

www.rsc.org/advances reactor control for their use as industrial biocatalysts. ${ }^{2 c, 4}$ Moreover, immobilization has been developed as a tool that, if properly used, may allow the improvement of other enzyme properties, such as stability, activity, selectivity, specificity or resistance to inhibition. ${ }^{5}$

Lipases have a peculiar mechanism of action, called interfacial activation. ${ }^{6}$ Most lipases have two different conformations, open and closed conformation, where the active center may be secluded by a polypeptide chain from the medium. ${ }^{6-8}$ This open form is unstable in aqueous medium, but becomes stabilized by adsorption on hydrophobic interfaces, such as drops of oils. ${ }^{6 c, 9}$ This adsorption of the open form of the lipase also occurred on any hydrophobic surface, like a hydrophobic protein, another lipase in its open form, or a support bearing hydrophobic surfaces. ${ }^{\mathbf{1 0}}$

In this regard, octyl-agarose has been proposed for a long time as a simple method to reach a one-step immobilization, stabilization, purification and hyperactivation protocol for many lipases. ${ }^{\mathbf{1 0} \boldsymbol{c}, \mathbf{1 1}}$ This support has been used to immobilize many enzymes that have been employed in many different 
reactions. ${ }^{12}$ Although the adsorption of lipases on octyl-agarose beads is quite strong, the enzyme may become released from the support if the derivative is incubated in the presence of high concentrations of organic cosolvents (used to solubilize some substrates or products), ${ }^{13}$ or in presence of detergents (used to modulate enzyme properties). ${ }^{\mathbf{1 1 a}, \mathbf{1 4}}$ Moreover, lipase desorption may occur after enzyme inactivation, contaminating the medium and losing one of the advantages of employing immobilized enzymes.

Crosslinking of the immobilized enzymes on octyl-agarose beads with aldehyde-dextran has been proposed as a way to prevent the enzyme release of the enzyme from the support. ${ }^{13,15}$ In fact, crosslinking with glutaraldehyde may give a similar effect, because lipases immobilize very rapidly on these supports and the enzyme molecules are packed together. ${ }^{\mathbf{1 6}}$

In this paper, a new strategy to use octyl-agarose beads to immobilize, purify, stabilize and hyperactivate lipases (and useful to be used in the presence of organic solvents or detergents) is proposed. It is based on the idea of heterofunctional supports, bearing different groups on the support surface with different functions that may permit to control immobilization. ${ }^{17}$ In this case, it is based on the conversion of octylagarose into a heterofunctional octyl-glyoxyl support. Crosslinked octyl agarose beads have some diols (resulting from the opening of the epoxy moieties during the support preparation) that may be easily oxidized to glyoxyl groups by oxidation with periodate. This makes immobilization of the enzyme possible via a first interfacial activation (with the advantages that this approach has) followed by covalent attachment(s) to avoid undesired enzyme release. Using hierarchical mesomacroporous silica, there is a recent report on the construction of octyl/glyoxyl heterofunctional supports, with good results in stabilization, but without a discussion on the advantages and drawbacks of the different preparations (was used in organic media) nor a clear demonstration of the establishment of covalent attachment between the enzyme and the support. ${ }^{18}$

Glyoxyl activated supports have been proposed as very suitable candidates to stabilize enzyme by multipoint covalent attachment via reaction with the primary amino groups of the enzyme. ${ }^{19}$ For developing this new strategy, the glyoxyl residues have a further advantage; they cannot immobilize soluble enzymes at $\mathrm{pH} 7$, because protein immobilization on glyoxyl supports requires the simultaneous production of, at least, two imino attachments. ${ }^{20}$ This permits that, at non alkaline $\mathrm{pH}$ value, the immobilization of the enzyme on the glyoxyl-octyl heterofunctional supports may be expected to proceed via interfacial activation. ${ }^{\mathbf{1 9 , 2 0 b}}$ Later, the proximity of the enzyme to the support, the addition of a thiol compound ${ }^{21}$ or the increase of the $\mathrm{pH}^{\mathbf{2 1 a}}$ could permit to increase the reactivity of the protein residues to have a covalent linkage between enzyme and support (after reduction a very stable secondary amino bond). ${ }^{17}$ Thus, this immobilized enzyme cannot be released to the medium under any circumstance. Obviously, this strategy requires at least one primary amino group of the enzyme to be located in a position where it can react with the support after adsorption on the enzyme.
The strategy has been assayed using 4 different enzymes. Lipase B from Candida antarctica (CALB) is one of the most used lipases in biocatalysis. ${ }^{22}$ The $3 \mathrm{D}$-protein structure of this lipase has been resolved. ${ }^{23}$ Although it has a very small lid and does not suffer from an increase in activity by interfacial activation, it may still become adsorbed on hydrophobic surfaces. Lipases from Thermomyces lanuginosus (TLL) ${ }^{24}$ and from Rhizomucor miehie (RML), ${ }^{25}$ have been also utilized, they have a proper lid and are probably among the most popular lipases after CALB. We have also included Lecitase Ultra in these studies, a commercial chimeric phospholipase built from the gen of the lipase from Thermomyces lanuginosus (to obtain good stability) and that of the phospholipase from Fusarium oxysporum (to get the phospholipase activity). ${ }^{26}$ The activity will be assayed with different substrates to check if the enzyme specificity is changed by the likely distortions on its structure produced by the covalent attachment, as it has been reported in many papers dealing with the immobilization of lipases. ${ }^{27}$

\section{Materials and methods}

\subsection{Materials}

Solutions of lipase B from C. antarctica (CALB) (6.9 mg of protein per $\mathrm{mL}$ ), lipase from Thermomyces lanuginosus (TLL) (36 mg of protein per $\mathrm{mL}$ ), lipase from Rhizomucor miehie (RML) (13.7 mg of protein per $\mathrm{mL}$ ) and the phospholipase Lecitase Ultra (16 $\mathrm{mg}$ of protein per $\mathrm{mL}$ ) were a kind gift from Novozymes (Spain). Octyl-agarose beads were from GE Healthcare. Methyl mandelate, ethyl hexanoate, $p$-nitrophenyl butyrate ( $p$-NPB) were from Sigma Chemical Co. (St. Louis, MO, USA). All reagents and solvents were of analytical grade.

\subsection{Standard determination of enzyme activity}

This assay was performed by measuring the increase in absorbance at $348 \mathrm{~nm}$ produced by the released $p$-nitrophenol in the hydrolysis of $0.4 \mathrm{mM}$-NPB in $100 \mathrm{mM}$ sodium phosphate at $\mathrm{pH}$ 7.0 and $25{ }^{\circ} \mathrm{C}\left(\varepsilon\right.$ under these conditions is $\left.5150 \mathrm{M}^{-1} \mathrm{~cm}^{-1}\right)$. To start the reaction, $50-100 \mu \mathrm{L}$ of lipase solution or suspension was added to $2.5 \mathrm{~mL}$ of substrate solution. One international unit of activity $(U)$ was defined as the amount of enzyme that hydrolyzes $1 \mu \mathrm{mol}$ of $p$-NPB per minute under the conditions described previously. Protein concentration was determined using Bradford's method ${ }^{28}$ and bovine serum albumin was used as the reference.

\subsection{Preparation of glyoxyl supports}

The preparation of both glyoxyl supports (directly agarose 4BCL or using octyl agarose 4BCL) respectively activated with 30 or $25 \mu \mathrm{mol}$ of aldehyde groups per $\mathrm{g}$ of wet support was carried out by directly oxidizing the diols of the support using sodium periodate (an equimolecular ratio was used in the reaction) following the standard protocol described in. ${ }^{19,20} \mathrm{~A}$ wet support is defined as the agarose beads with the pores full of aqueous medium, but without interparticle water (dried using vacuum filter). The suspensions containing the supports and the sodium periodate were gently stirred for $3 \mathrm{~h}$ at $25{ }^{\circ} \mathrm{C}$, and then 
the supports were filtered and washed with distilled water. The non-consumed periodate was measured by titration of the filtrate with KI in saturated bicarbonate. ${ }^{29}$

\subsection{Immobilization of enzymes}

2.4.1. Immobilization of enzymes on octyl (OC) and octylglyoxyl (OCGLX) supports. The immobilization was performed using 1 or $5 \mathrm{mg}$ of protein per $\mathrm{g}$ of wet support, except in maximum loading determination where the volume of enzyme was increased to reach the $60 \mathrm{mg}$ of enzyme per $\mathrm{g}$ of support. The commercial samples of the enzymes were diluted in the corresponding volume of $5 \mathrm{mM}$ sodium phosphate at $\mathrm{pH} 7$. Then, the supports were added. The activity of both supernatant and suspension was followed using $p$-NPB. After immobilization the suspension was filtered and the supported enzyme was washed several times with distilled water.

In the case of OCGLX, the washed immobilized enzyme was re-suspended in certain instances at pH 10 for different times, to favor the enzyme-support covalent reaction. ${ }^{20 a}$

2.4.2. Immobilization of enzymes on glyoxyl (GLX) support. The immobilization was performed using 1 or $5 \mathrm{mg}$ of protein per $\mathrm{g}$ of wet support. The enzymes were diluted in a $50 \mathrm{mM}$ sodium bicarbonate buffer at $\mathrm{pH} 10$. Then, the support was suspended in the enzyme solution under gentle stirring. Periodically, samples of the supernatant and suspension were withdrawn, and the enzyme activity was measured as described above.

2.4.3. Reduction with sodium borohydride. To end the enzyme-support covalent reaction, solid sodium borohydride was added to a concentration of $1 \mathrm{mg} \mathrm{mL}^{-1}$ to the OCGLX and GLX suspensions (at $\mathrm{pH}$ 10) and were submitted to gentle stirring for $30 \mathrm{~min}$. This treatment reduces reversible Schiff's bases to very stable secondary amino bonds and unreacted aldehydes groups to fully inert hydroxy groups. ${ }^{19-21}$ Finally the reduced derivatives were filtered, washed with abundant distilled water and stored at $4{ }^{\circ} \mathrm{C}$.

\subsection{Desorption of the enzyme from the supports}

To analyze if the enzymes were really covalently attached to the support, and to keep only the covalently attached enzyme molecules for further studies, the reduced OCGLX derivatives were incubated with a growing concentration of the appropriate detergent, using OC derivatives as reference. This treatment only releases the enzyme molecules adsorbed by interfacial activation. Thus, samples of $1 \mathrm{~g}$ of different biocatalysts were suspended at $25^{\circ} \mathrm{C}$ in $10 \mathrm{~mL}$ of $10 \mathrm{mM}$ sodium phosphate at $\mathrm{pH}$ 7. Then, Triton X-100 (for CALB, RML and Lecitase) or CTAB (for TLL) were progressively added to a final concentration of $1.5 \%$ and $2 \%(\mathrm{v} / \mathrm{v})$ respectively. Intervals of $30 \mathrm{~min}$ were allowed before taking a sample of the supernatant to determine the released enzyme and performing a new detergent addition. A reference suspension, having inert support and the same amount of lipase was submitted exactly to the same treatment, to detect the effects of the detergent on enzyme activity or stability.

\subsection{Study of the stability of the different lipase biocatalyst}

2.6.1. Thermal inactivation of different enzyme immobilized preparations. $1 \mathrm{~g}$ of immobilized enzyme was suspended in $5 \mathrm{~mL}$ of $50 \mathrm{mM}$ of sodium acetate at $\mathrm{pH} 5$, sodium phosphate at $\mathrm{pH} 7$ or sodium bicarbonate at $\mathrm{pH} 9$ at different temperatures. Periodically, samples were withdrawn and the activity was measured using $p$-NPB. Half-lives were calculated from the observed inactivation courses.

2.6.2. Inactivation of different preparations in the presence of organic co-solvents. Enzyme preparations were incubated in mixtures of acetonitrile or 1,4-dioxane/100 mM Tris- $\mathrm{HCl}$ pH 7 at different temperatures. Periodically, samples were withdrawn and the activity was measured using $p$-NPB as described above. Half-lives were calculated from the observed inactivation courses. The organic co-solvents presented in the samples did not have a significant effect on enzyme activity (results not shown).

\subsection{Determination of the hydrolytic activity of the biocatalyst versus different substrates}

2.7.1. Hydrolysis of ethyl hexanoate. Enzyme activity was determined by using ethyl hexanoate; $200 \mathrm{mg}$ of the immobilized preparations were added to $1 \mathrm{~mL}$ of $25 \mathrm{mM}$ substrate in $50 \mathrm{mM}$ sodium phosphate at $\mathrm{pH} 7$, in some instances containing $\mathrm{CH}_{3} \mathrm{CN}$ to have a homogenous system instead of a biphasic system. All experiments were carried out at $25^{\circ} \mathrm{C}$ under continuous stirring. The conversion degree was analyzed by RP-HPLC (Spectra Physic SP 100 coupled with an UV detector Spectra Physic SP 8450) using a Kromasil C18 $(15 \mathrm{~cm} \times 0.46 \mathrm{~cm})$ column. Samples $(20 \mu \mathrm{L})$ were injected and eluted at a flow rate of $1.0 \mathrm{~mL} \min ^{-1}$ using acetonitrile/10 $\mathrm{mM}$ ammonium acetate aqueous solution (50:50, v/v) and $\mathrm{pH} 3.2$ as mobile phase and UV detection was performed at $208 \mathrm{~nm}$. When a substrate/ enzyme suspension biphasic system existed, a sample of $100 \mu \mathrm{L}$ was withdrawn under very vigorous stirring, mixed with a volume of acetonitrile and filtered before injection in the HPLC. Hexanoic acid had a retention time of 3.4 minutes while the ester presented a retention time of 14.2 minutes. One unit of enzyme activity was defined as the amount of enzyme necessary to produce $1 \mu \mathrm{mol}$ of hexanoic acid per minute under the conditions described above. Activity was determined by triplicate with a maximum conversion of $20-30 \%$, and data are given as average values.

2.7.2. Hydrolysis of methyl mandelate. Enzyme activity was also determined using methyl mandelate. $200 \mathrm{mg}$ of the immobilized preparations were added to $1 \mathrm{~mL}$ of $50 \mathrm{mM}$ substrate in $50 \mathrm{mM}$ sodium phosphate at $\mathrm{pH} 7$ and $25^{\circ} \mathrm{C}$ under continuous stirring. In some instances, organic solvents were added. The conversion degree was analyzed by RP-HPLC (Spectra Physic SP 100 coupled with an UV detector Spectra Physic SP 8450) using a Kromasil C18 $(15 \mathrm{~cm} \times 0.46 \mathrm{~cm})$ column. Samples $(20 \mu \mathrm{L})$ were injected and eluted at a flow rate of $1.0 \mathrm{~mL} \mathrm{m^{-1 }}$ using acetonitrile $/ 10 \mathrm{mM}$ ammonium acetate (35:65, v/v) at pH 2.8 as mobile phase and UV detection was performed at $230 \mathrm{~nm}$. The acid presented a retention time of 2.4 minutes while the ester had a retention time of 4.2 minutes. One unit of enzyme activity was defined as the amount of 
enzyme necessary to produce $1 \mu$ mol of hexanoic acid per minute under the conditions described above. Activity was determined by triplicate with a maximum conversion of $20-30 \%$, and data are given as average values.

\subsection{SDS-PAGE experiments}

SDS-polyacrylamide gel electrophoresis was performed according to Laemmli ${ }^{30}$ using a Miniprotean tetra-cell (Biorad), 12\% running gel in a separation zone of $9 \mathrm{~cm} \times 6 \mathrm{~cm}$, and a concentration zone of $5 \%$ polyacrylamide. One hundred milligrams of the immobilized enzyme samples was re-suspended in $1 \mathrm{~mL}$ of rupture buffer (2\% SDS and 10\% mercaptoethanol), boiled for $5 \mathrm{~min}$ and a $20 \mu \mathrm{L}$ aliquot of the supernatant was used in the experiments. This treatment released all enzyme just interfacially activated on the support. ${ }^{\mathbf{1 1 a}}$ Gels were stained with Coomassie brilliant blue. Low molecular weight markers from Fermentas were used (10-200 kDa).

\section{Results}

\subsection{Preparation of OCGLX agarose}

OC-agarose was submitted to oxidation with sodium periodate. The results point out that $25 \mu \mathrm{mol}$ aldehyde groups per $\mathrm{g}$ of wet support could be introduced (see Fig. 1). The support was incubated in the presence of Schiff's reactive, confirming the existence of aldehyde moieties on the support. After reduction with sodium borohydride, this reactivity disappeared. The support modification with ethylenediamine permitted to introduce one primary and one secondary amino groups, ${ }^{31}$ their titration in a pHstat confirmed the values obtained using determination of remaining periodate.

Thus, a support bearing octyl moieties plus $25 \mu \mathrm{mol}$ aldehyde groups per $\mathrm{g}$ of wet support have been easily prepared from the commercial sample of OC-agarose. Using naked 4BCL agarose beads activated with glycidol, around $70 \mu \mathrm{mol}$ glyoxyl groups per $\mathrm{g}$ could be introduced, ${ }^{32}$ thus the octyl-glyoxyl support has a reasonable amount of aldehyde groups for our purposes. The direct oxidation of non-activated 4BCL agarose with periodate produced $30 \mu \mathrm{mol}$ aldehyde groups per $\mathrm{g}$ of wet support. This was the support used as reference of covalently

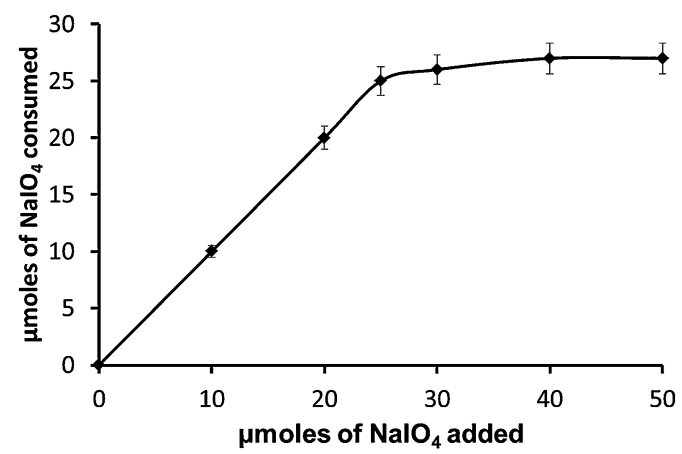

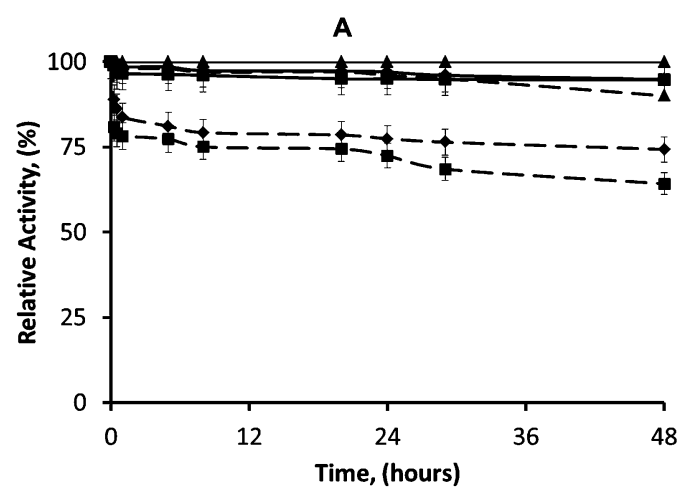

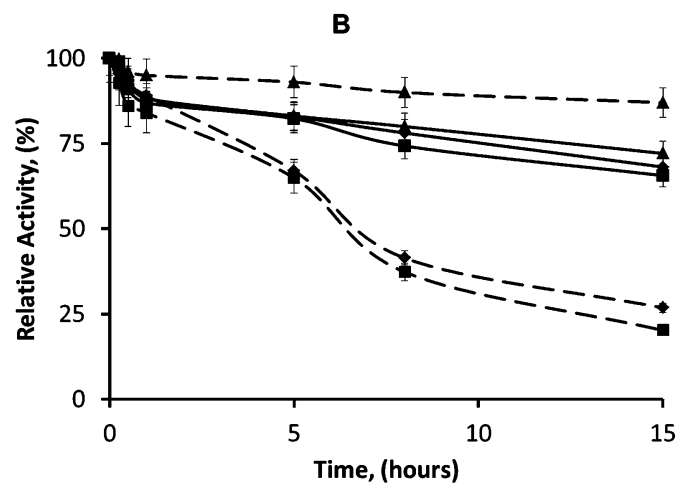

C

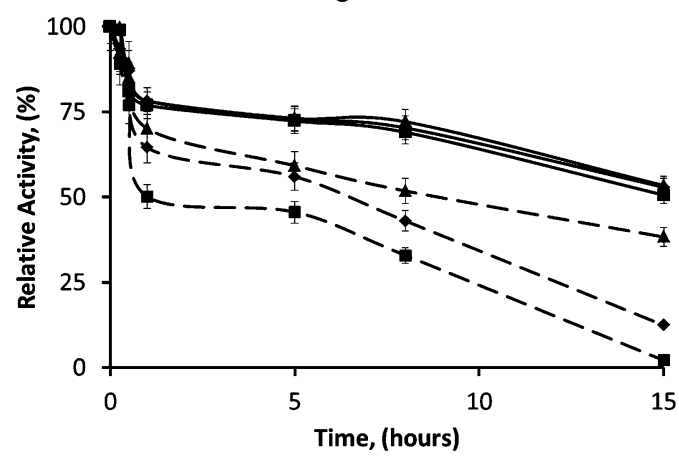

D

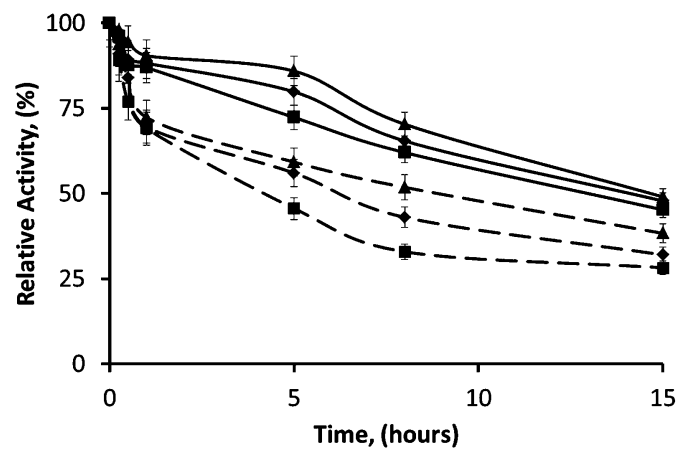

Fig. 2 Immobilization courses of different lipases on glyoxyl agarose support. Experiments have been performed as described in Section 2. Immobilization on GLX; Panel A: (CALB), Panel B: (Lecitase), Panel C: (RML) and Panel D: (TLL). Rhombus (suspension), square (Supernatant), triangle (Soluble enzyme), solid black line $(\mathrm{pH} 10$ without mercaptoethanol), dash line ( $\mathrm{pH} 10$ with mercaptoethanol).

Fig. 1 Oxidation of OC support to obtain OCGLX agarose support. Experiments have been performed as described in Section 2. 
bonded-only biocatalyst even though it presented some more glyoxyl groups than the OCGLX.

\subsection{Immobilization of lipases on octyl, glyoxyl and octyl glyoxyl}

Fig. 2 and 3 (and Fig. 1 in ESI $\dagger$ ) show the immobilization courses of the 4 lipases on the different supports. All lipases immobilized slower on GLX agarose than on any of the octyl supports. Moreover, in three of the four cases the enzymes became almost fully inactivated when immobilizing on glyoxyl support (Fig. 2). The enzyme stability at pH 10 was low in certain cases. ${ }^{33}$ CALB immobilized around $30 \%$ of the offered activity after $48 \mathrm{~h}$, the activity of the suspension remained almost unaltered. The use of mercaptoethanol improved the immobilization yields in all cases, but only in the case of CALB this treatment permitted to have biocatalysts with higher activities, as in the other cases the enzymes were inactivated during immobilization. Thus, only GLX-CALB could be prepared for further comparisons with OCGLX biocatalysts.

At $\mathrm{pH} 7$, the GLX supports were unable to immobilize any of the lipases (results not shown), this experiment is necessary to confirm that using OCGLX, the first immobilization on it is via interfacial activation. This is expected, as protein immobilization via glyoxyl groups requires the involvement of several amino groups of the protein,,$^{\mathbf{1 9 2 0}}$ and at $\mathrm{pH} 7$ the $\varepsilon$-amino groups of the Lys residues will be in an ionized form and, therefore, unreactive.

Using OC-support (Fig. $1 \mathrm{~S} \dagger$ ), immobilization rates are very high, and enzyme activity significantly increased upon immobilization, as previously reported in many instances. ${ }^{\mathbf{1 0}, \mathbf{1 1 a}} \mathrm{Lec}$ itase reached an activity of $270 \%$ compared to the initial one, RML and TLL activity increase to more than a 300\%, CALB is the only enzyme whose activity remained almost unaltered after immobilization on octyl, very likely due to the very small lid that not fully secludes the active center from the reaction media. ${ }^{23}$

The use of OCGLX supports (Fig. 3) produced a slightly higher immobilization rate when compared to OC supports (see Fig. 1S $\dagger$ ) in all cases (perhaps because the support is now slightly more hydrophobic, see Scheme 1), and the effects on the enzyme activity are similar to those observed using octyl agarose.

To study if the enzyme molecules had been covalently attached to the support, the immobilized preparations were reduced using borohydride and submitted to analysis via SDS-PAGE (this prevented the release of the enzyme molecules covalently attached to the reaction medium by this treatment). It was observed that most of the immobilized enzyme molecules could be released to the media (results not shown) after boiling the biocatalysts in the presence of SDS and mercaptoethanol, suggesting that at $\mathrm{pH} 7$ the reactivity of the amino groups of the enzymes was not high enough to produce a covalent attachment with the glyoxyl groups, even though the enzyme is very near to the support and the reaction is an "intramolecular reaction". ${ }^{34}$

Thus, we decided to increase the $\mathrm{pH}$ value of the medium after enzyme adsorption on octyl-glyoxyl agarose to favor the enzyme-support reactivity. At alkaline $\mathrm{pH}$ the $\varepsilon$ amino group of
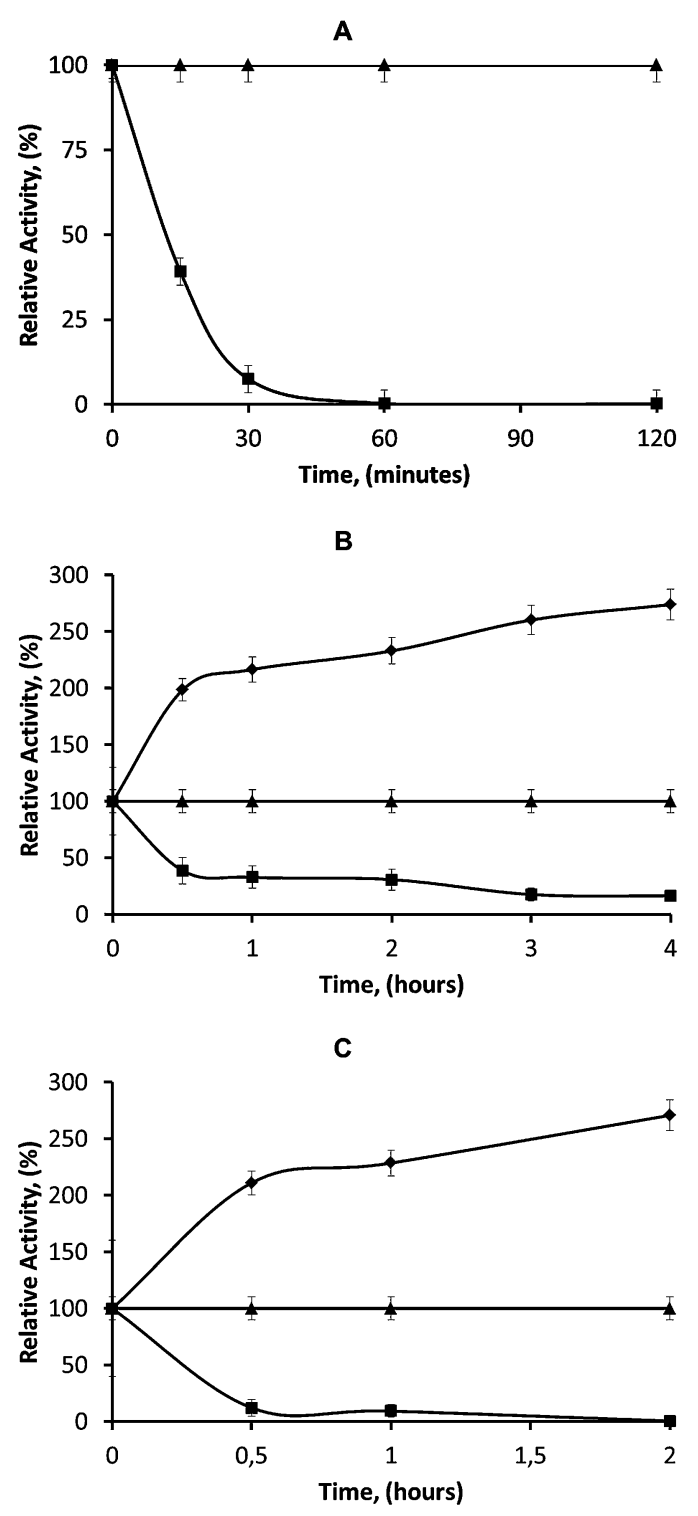

D

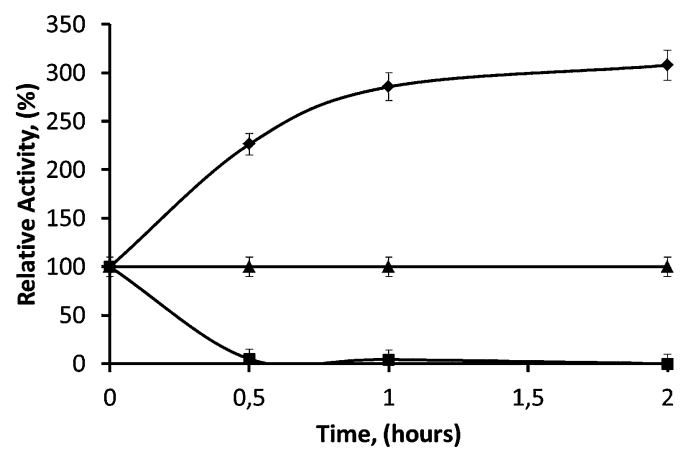

Fig. 3 Immobilization courses of different lipases on octyl-glyoxyl agarose supports. Experiments have been performed as described in Section 2. Panel A (CALB): triangles, solid black line: soluble enzyme; square, dash line: supernatant. Panel B (Lecitase): rhombus, solid black line: suspension; squares, solid black line: supernatant; triangles, solid black line: soluble enzyme. Panel C (RML): rhombus, solid black line: suspension; squares, solid black line: supernatant; triangles, solid black line: soluble enzyme. Panel D (TLL): rhombus, solid black line: suspension; squares, solid black line: supernatant; triangles, solid black line: soluble enzyme. 
the Lys will greatly increase its reactivity with glyoxyl groups. ${ }^{\mathbf{2 0 a}}$ Moreover, mercaptoethanol has been reported to be able to stabilize the imino bonds. Thus we studied the effect of mercaptoethanol to covalently immobilize the adsorbed enzyme molecules. ${ }^{35}$ Fig. $2 S$ in ESI $\dagger$ shows the effect of this incubation at pH 10 on the activities of the four enzymes.

After $24 \mathrm{~h}$ of incubation at $\mathrm{pH} 10$, octyl-glyoxyl-CALB retained the enzyme activity almost unaltered (98\%). In the case of Lecitase, the preparation decreased its activity by around $17 \%$ in $4 \mathrm{~h}$. In the presence of mercaptoethanol, the decrease in activity was slightly higher. Using RML, after $4 \mathrm{~h}$ of incubation enzyme activity decreased to $41 \%$ in the absence of mercaptoethanol and to $32 \%$ in the presence of mercaptoethanol. TLL decreased the activity after incubation at pH 10 after 4 h by only $20 \%$, becoming $28 \%$ in the presence of mercaptoethanol. This result greatly contrasted with the results obtained when TLL was immobilized directly at pH 10 on glyoxyl agarose, where the enzyme was almost fully inactivated. ${ }^{33}$ This could be explained by the stabilization toward high $\mathrm{pH}$ caused by the interfacial activation of the enzyme on the octyl support. ${ }^{24}$

The SDS-PAGE analysis (Fig. 4) of the enzyme desorbed from the supports after boiling in the presence of SDS showed that for CALB, RML and Lecitase, only around $15 \%$ of the enzyme could be released, that is, more than $85 \%$ of the enzyme molecules were covalently attached to the support in the worst case scenario (CALB). Using TLL the percentage of enzyme that did not become covalently immobilized on the OCGLX support was higher than in the other cases over $30 \%$ of the enzyme was released by this treatment. The presence of mercaptoethanol has no relevance in altering these results, suggesting that at $\mathrm{pH} 10$ the stabilization of the imino bonds by the thiol compound is not necessary. As expected due to the reversibility of the imino bonds, nonreduced OCGLX preparations released a quantity of protein that produced a band in SDS-PAGE with an intensity similar to that obtained by analyzing the octyl preparation (Fig. 4).

To compare enzyme molecules just adsorbed on OC supports versus the enzyme molecules that were moreover covalently immobilized on the OCGLX matrices, it seemed convenient to eliminate all non-covalently immobilized enzymes from the

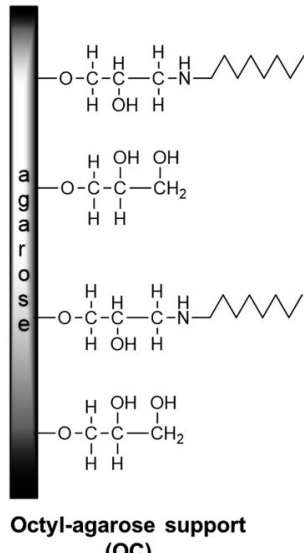

(OC)

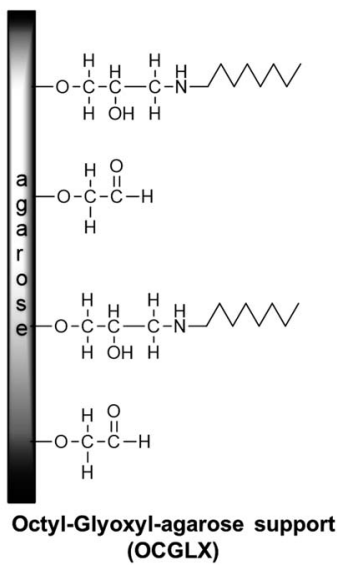

(OCGLX)
Scheme 1 Preparation of OCGLX supports. supports. To reach this goal, the enzyme preparations were washed with the corresponding detergent concentration able to release all the enzyme molecules from the octyl support (optimization of the washing conditions is not shown). SDS-PAGE analysis of the 4 detergent washed octyl-glyoxyl preparations (Fig. 4) revealed that most enzyme molecules remaining in the support were covalently attached to the support.

The loading capacities of the octyl and octyl-glyoxyl were identical as the immobilization cause was the same for all biocatalyst (e.g., 17-20 mg per wet gram using CALB). However, we used moderate loadings to prevent diffusion artifacts in the further analysis (see methods).

The properties of these preparations were evaluated, compared to octyl and, in the case of CALB, to glyoxyl derivatives.

\subsection{Thermal stability}

Table 1 shows the half-lives of the different enzyme preparations at $\mathrm{pH}$ 5, 7 and 9. Studying CALB, OCGLX preparations were more stable than OC-CALB preparations, except at pH 5. The stabilization factor was over 10 at $\mathrm{pH} 9$ and 4.5 at $\mathrm{pH}$ 7. The incubation of OCGLX in the presence of mercaptoethanol to stabilize the enzyme-support imino bonds during biocatalyst preparation reduced the stability of the enzyme, although it remained more stable than the OC preparation. GLX-CALB was by far the least stable preparation in all studied $\mathrm{pH}$ values. Using Lecitase, at $\mathrm{pH} 5$, the stabilization of the OCGLX compared to the OC preparations reached a value of 12 , at $\mathrm{pH} 7$ was 7.7 folds, and at pH 9 was 4.9, mercaptoethanol presence during alkaline incubation to get covalent bonds did not alter enzyme stability. When RML was studied, stabilization values
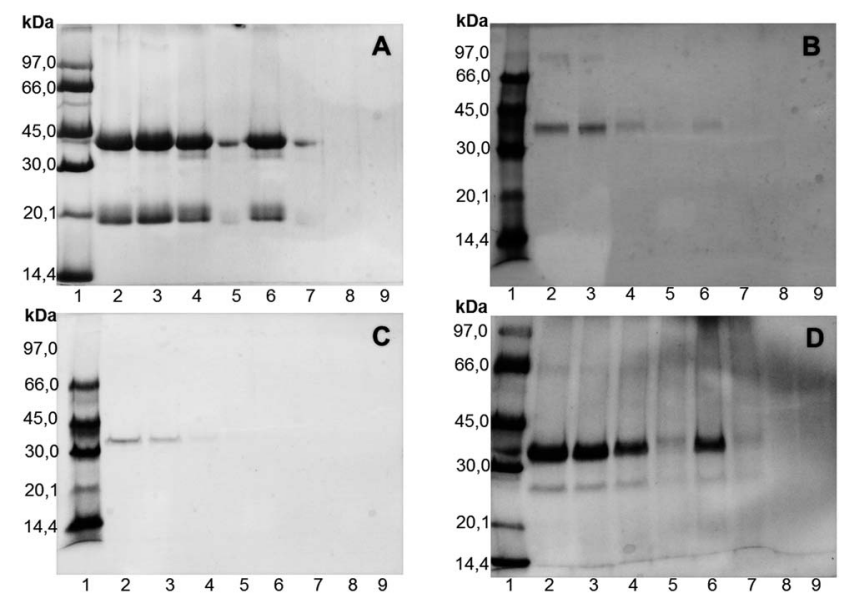

Fig. 4 SDS-PAGE analysis of different biocatalysts preparations. The immobilized enzymes were submitted to the processes described in Section 2. Panel A: CALB, Panel B: Lecitase, Panel C: RML and Panel D: TLL. Lane 1: molecular weight marker, Lane 2: OC, Lane 3: OCGLX, Lane 4: OCGLX incubated to $\mathrm{pH} 10$, Lane 5: OCGLX incubated to $\mathrm{pH}$ 10 and reduced with $\mathrm{NaBH}_{4}$, Lane 6: OCGLX incubated to $\mathrm{pH} 10$ with mercaptoethanol, Lane 7: OCGLX incubated to $\mathrm{pH} 10$ with mercaptoethanol and reduced with $\mathrm{NaBH}_{4}$, Lane 8: OCGLX incubated to $\mathrm{pH}$ 10, reduced with $\mathrm{NaBH}_{4}$ and washed with detergent, Lane 9: OCGLXCALB incubated to $\mathrm{pH} 10$ with mercaptoethanol, reduced with $\mathrm{NaBH}_{4}$ and washed with detergent. 
were 12 at $\mathrm{pH} 5,4$ at $\mathrm{pH} 7$ and 7.8 at $\mathrm{pH}$ 9. The presence of mercaptoethanol during alkaline incubation produced a light increase of enzyme stability at $\mathrm{pH} 7$, had not effect at $\mathrm{pH} 9$ and was even negative at $\mathrm{pH} 5$.

OCGLX-TLL was the only exception, this preparation being less stable than the enzyme which was only adsorbed, OC-TLL even by a 5 fold factor at $\mathrm{pH}$ 7. This decrease in stability due to the covalent immobilization was complex to understand. To analyze likely causes of this destabilization after immobilization on OCGLX compared to OC, we prepared different biocatalysts with the different treatments that suffer the OCGLX-TLL except the possibility of covalent reaction between enzyme and support. The enzyme was immobilized on reduced OCGLX (to check if the chemical changes in the support can be responsible for the lower stability), a support that is identical to the final OCGLX-TLL, but that cannot covalently react with the enzyme. An amount of this immobilized enzyme was incubated at $\mathrm{pH} 10$, to check if the incubation produced any conformational or chemical change in the enzyme or on the support that could generate some decrease on enzyme stability. Finally, a portion of this alkaline incubated preparation was reduced with sodium borohydride, to check if the reduction step was responsible for the decrease on enzyme stability (TLL has several disulfide bonds). The enzyme stability of these three preparations remained similar to that of the OC-TLL. Thus, the reaction between enzyme and support is the likeliest explanation for this decrease in stability; perhaps some distortion caused during alkaline incubation can produce a unstable enzyme structure that the low number of covalent attachments between enzyme and support cannot stabilize (the fact that to have just one covalent bond with this enzyme is difficult suggested that achieving an intense multipoint attachment is not very likely).

\subsection{Stability in organic solvents}

The different enzyme derivatives were incubated in different organic solvents and concentrations, looking for conditions where the different OC-enzymes preparations became significantly inactivated in a reasonable time (Table 1).

In opposition to thermal inactivations, OC-CALB preparation, inactivated at $30{ }^{\circ} \mathrm{C}$ in $80 \%$ dioxane at $\mathrm{pH} 7$, was the least stable CALB preparation, including the GLX-CALB that was now $33 \%$ more stable. The most stable preparation was OCGLX-CALB, with a stabilization factor of 1.67 , and results when the preparation of OCGLX-CALB was performed in the presence of mercaptoethanol were worse, with no significant difference with the OC-CALB stability. The comparatively low stability of the non-covalent preparation compared to the covalent one could be related to the weakening of the enzyme/ support interactions caused by the cosolvent.

OCGLX-Lecitase in $45 \%$ acetonitrile at $\mathrm{pH} 7$ and $30{ }^{\circ} \mathrm{C}$ was over 3 folds more stable than OC-Lecitase. OCGLX-RML was 6 folds more stable than OC-RML in $30 \%$ acetonitrile at $30{ }^{\circ} \mathrm{C}$. The TLL half live of OCGLX in $60 \%$ dioxane at $\mathrm{pH} 7$ and $30{ }^{\circ} \mathrm{C}$ was 11.9 times higher than that of OC-TLL. In these three cases, the incubation in the presence of mercaptoethanol during the preparation of the OCGLX biocatalysts did not alter the final results. Except in the case of CALB, the stabilizations observed in the presence of organic solvents were quite significant by using OCGLX instead of OC supports, suggesting that the covalent immobilization may play an important role in enzyme stability in this medium.

\subsection{Desorption of enzyme molecules during inactivation from octyl supports}

As previously visualized (see Fig. 4), the enzyme cannot be desorbed during inactivation from OCGLX supports, even in a SDS-PAGE treatment the enzyme remains attached to the support, because of the high stability of the secondary amino bonds formed between enzyme and support after reduction. To check if OC-lipase preparations released enzyme molecules during the thermal or organic solvents inactivations, the amount of protein adsorbed to the support before and after

Table 1 Half-lives of the different biocatalyst under different conditions (in minutes). CALB ( $\mathrm{pH} 5-80^{\circ} \mathrm{C}, \mathrm{pH} 7-70^{\circ} \mathrm{C}, \mathrm{pH} 9-60{ }^{\circ} \mathrm{C}$ ), LU and RML $\left(\mathrm{pH} 5-60^{\circ} \mathrm{C}, \mathrm{pH} 7-50^{\circ} \mathrm{C}, \mathrm{pH} 9-45^{\circ} \mathrm{C}\right)$ and $\mathrm{TLL}\left(70{ }^{\circ} \mathrm{C}\right.$ at $\mathrm{pH} 5$ and $\mathrm{pH} 7,60^{\circ} \mathrm{C}$ at pH 9). All enzymes derivatives were incubated at $30{ }^{\circ} \mathrm{C}$ in organic solvents

Experimental conditions

\begin{tabular}{|c|c|c|c|c|c|c|c|}
\hline Biocatalyst & pH 5 & pH 7 & pH 9 & Dioxane $80 \%$ & ACN $45 \%$ & $\mathrm{ACN} 30 \%$ & Dioxane $60 \%$ \\
\hline OCCALB & $150 \pm 7.5$ & $24 \pm 1.2$ & $10 \pm 0.5$ & $144 \pm 7.2$ & - & - & - \\
\hline OCGLXCALB pH 10 & $120 \pm 6.0$ & $108 \pm 5.4$ & $100 \pm 5.0$ & $240 \pm 12.0$ & - & - & - \\
\hline OCGLXCALB pH 10 - mercaptoethanol & $108 \pm 5.4$ & $88 \pm 4.4$ & $80 \pm 4.0$ & $150 \pm 7.5$ & - & - & - \\
\hline GLXCALB & $5 \pm 0.3$ & $5 \pm 0.3$ & $5 \pm 0.3$ & $192 \pm 9.6$ & - & - & - \\
\hline OCLU & $5 \pm 0.3$ & $110 \pm 5.5$ & $105 \pm 5.3$ & - & $5 \pm 0.3$ & - & - \\
\hline OCGLXLU pH 10 & $60 \pm 3.0$ & $850 \pm 42.5$ & $515 \pm 25.8$ & - & $15 \pm 0.8$ & - & - \\
\hline OCGLXLU pH 10 - mercaptoethanol & $60 \pm 3.0$ & $850 \pm 42.5$ & $515 \pm 25.8$ & - & $15 \pm 0.8$ & - & - \\
\hline OCRML & $10 \pm 0.5$ & $42 \pm 2.1$ & $5 \pm 0.3$ & - & - & $5 \pm 0.3$ & - \\
\hline OCGLXRML pH 10 & $120 \pm 6.0$ & $168 \pm 0.9$ & $39 \pm 2.0$ & - & - & $30 \pm 1.5$ & - \\
\hline OCGLXRML pH 10 - mercaptoethanol & $100 \pm 5.0$ & $180 \pm 9.0$ & $42 \pm 2.1$ & - & - & $30 \pm 1.5$ & - \\
\hline OCTLL & $240 \pm 12.0$ & $150 \pm 7.5$ & $492 \pm 24.6$ & - & - & - & $72 \pm 3.6$ \\
\hline OCGLXTLL pH 10 & $180 \pm 9.0$ & $30 \pm 1.5$ & $150 \pm 7.5$ & - & - & - & $860 \pm 43.0$ \\
\hline OCGLXTLL pH 10 - mercaptoethanol & $210 \pm 10.5$ & $30 \pm 1.5$ & $150 \pm 7.5$ & - & - & - & $860 \pm 43.0$ \\
\hline
\end{tabular}


inactivations was compared using SDS-PAGE analysis. As stated before, the boiling of the OC-lipases in the presence of SDS released all protein from the OC support to the medium. Thus, the OC preparations of the 4 different enzymes before and after enzyme inactivation were submitted to this study. Fig. 5 shows that the amount of enzyme in octyl supports after enzyme inactivation in organic solvent significantly decreased during enzyme inactivation. The release of the enzyme covalently attached to the support via secondary amino bonds is no longer possible, increasing the interest of this new methodology. Thus, enzyme leakage from the octyl support could explain why the OCGLX preparations were much more stable than the OC biocatalysts in the presence of organic solvents. CALB was an exception, the enzyme did not seem to be released from the support during inactivation in organic media, and perhaps this explains why the stabilization observed with this enzyme in the presence of organic cosolvent was relatively low.

Furthermore, we performed a similar analysis on OC-enzyme preparations thermally inactivated in aqueous medium at different $\mathrm{pH}$ values. Fig. 6 shows that there was a massive release of the immobilized enzyme from the octyl support to the medium at high temperatures. The release of the enzyme molecules may be before or after enzyme inactivation, and, in all cases, the enzyme can be finally incorporated to the reaction media and contaminate the product. This can explain the positive effects of the covalent attachment in thermal inactivations. Lecitase did not release from the octyl support during thermal inactivation at any of the analyzed $\mathrm{pH}$ and $T$ values (the amount of enzyme that remained adsorbed on the support is very similar), but this did not prevent the clear stabilization of the enzyme using OCGLX support compared to the OC ones.

Thus, the prevention of the release of enzyme molecules from the support may be a reason for enzyme stabilization when using OCGLX, both in thermal and organic solvent inactivation. This is also important because if the enzyme is released from the support, it may contaminate the reaction media, an important point if the enzyme is used in food modification.
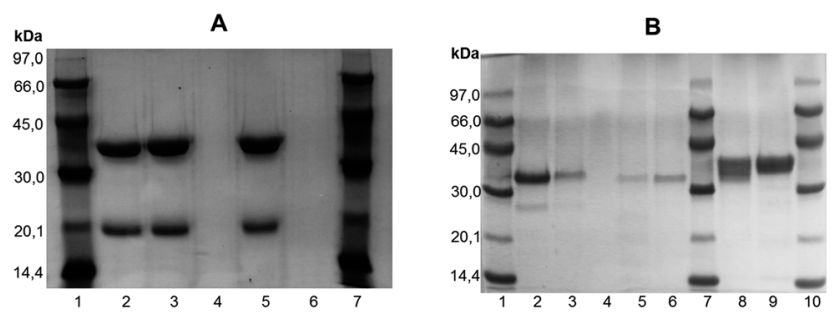

Fig. 5 SDS-PAGE analysis of different octyl-biocatalysts preparations after inactivation in the presence of organic solvents at $30^{\circ} \mathrm{C}$ for $8 \mathrm{~h}$. Experiments have been performed as described in Section 2. The gel shows the enzyme that remains bound to the support after inactivation. Panel A: OCCALB, Lanes 1 and 7: molecular weight marker, Lane 2: OCCALB, Lane 3: OCCALB incubated in $90 \%$ of dioxane and Lane 5: OCCALB incubated in $90 \%$ of ACN. Panel B: TLL, RML and Lecitase. Lanes 1, 7 and 10: molecular weight marker, Lane 2: OCTLL, Lane 3: OCTLL incubated in 60\% dioxane, Lane 5: OCRML incubated in 30\% ACN, Lane 6: OCRML, Lane 8: OCLecitase and Lane 9: OCLU incubated in $45 \% \mathrm{ACN}$.
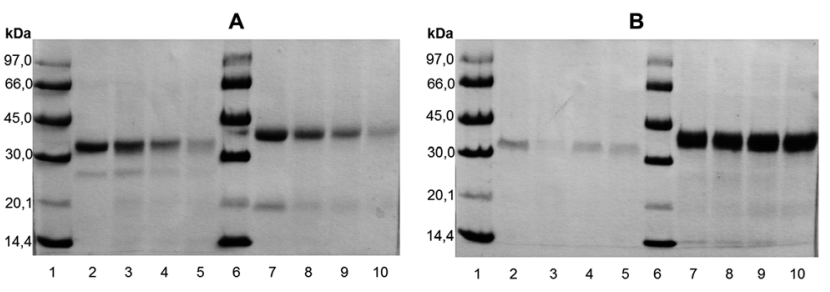

Fig. 6 SDS-PAGE analysis of different octyl biocatalysts preparations after thermal inactivation at different $\mathrm{pH}$ values for $8 \mathrm{~h}$. Experiments have been performed as described in Section 2 . The gel shows the enzyme that remains bound to the support after inactivation. Panel A: Lane 1: molecular weight marker, Lane 2: OCTLL, Lane 3: OCTLL incubated at $\mathrm{pH} 5$ and $70^{\circ} \mathrm{C}$, Lane 4: OCTLL incubated at $\mathrm{pH} 7$ and 70 ${ }^{\circ} \mathrm{C}$, Lane 5: OCTLL incubated at $\mathrm{pH} 9$ and $60{ }^{\circ} \mathrm{C}$, Lane 6: molecular weight marker, Lane 7: OCCALB, Lane 8: OCCALB incubated at $\mathrm{pH} 5$ and $70{ }^{\circ} \mathrm{C}$, Lane 9: OCCALB incubated at $\mathrm{pH} 7$ and $70{ }^{\circ} \mathrm{C}$, Lane 10 : OCCALB incubated at $\mathrm{pH} 9$ and $60{ }^{\circ} \mathrm{C}$. Panel B: Lane 1: molecular weight marker, Lane 2: OCRML, Lane 3: OCRML incubated at $\mathrm{pH} 5$ and $60^{\circ} \mathrm{C}$, Lane 4: OCRML incubated at $\mathrm{pH} 7$ and $50^{\circ} \mathrm{C}$, Lane 5: OCRML incubated at $\mathrm{pH} 9$ and $45^{\circ} \mathrm{C}$, Lane 6: molecular weight marker, Lane 7: OCLU, Lane 8: OCLU incubated at $\mathrm{pH} 5$ and $60^{\circ} \mathrm{C}$, Lane 9: OCLU incubated at $\mathrm{pH} 7$ and $50{ }^{\circ} \mathrm{C}$, Lane 10: OCLU incubated at $\mathrm{pH} 9$ and $45^{\circ} \mathrm{C}$.

\subsection{Activity of the different enzyme preparations}

Table 2 shows the activity of the different enzyme preparations versus two different substrates, methyl mandelate and ethyl hexanoate.

In the hydrolysis of methyl mandelate in aqueous media, OC and OCGLX-CALB presented very similar activity per $\mathrm{mg}$ of immobilized enzyme, almost triplicating the activity of the GLX preparation. The activity versus ethyl hexanoate was determined in growing concentrations of acetonitrile (from 50 to $90 \%$ ). The activity decreased in the presence of solvent, but this decrease on enzyme activity was sharper when using the OC-CALB than when using OCGLX (in 90\% acetonitrile this preparation presented $30 \%$ more activity than OC-CALB). GLX-CALB was 9 fold less active than OCGLX in 50\% acetonitrile and 4 times less active in $90 \%$.

Thus, the specificity of the GLX-CALB was different than that of OC preparations (comparing the results in water with both substrates), while the organic solvents have a lower impact on the enzyme activity of the covalent preparation. OC-and OCGLX preparations presented a similar specificity but different resistance to organic solvents.

Analyzing Lecitase, OC- and OCGLX-Lecitase presented a similar activity in the hydrolysis of methyl mandelate in aqueous media. However, in the hydrolysis of ethyl hexanoate in aqueous media, OCGLX-Lecitase is around 3 fold more active than OC-Lecitase. In the presence of $50 \%$ acetonitrile, this difference becomes almost 64 fold factor. OCGLX-RML (remember that incubation at alkaline $\mathrm{pH}$ value decreased the activity by almost a 3 fold factor using pNPB) is 4 fold less active in the hydrolysis of methyl mandelate than OC-RML. In the hydrolysis of ethyl hexanoate, OCGLX becomes slightly more active than OC-RML in fully aqueous media, and the differences become a factor of 2 in the presence of $50 \%$ acetonitrile. In the 
Table 2 Activity of the different biocatalyst versus methyl mandelate $(50 \mathrm{mM})$ and ethyl hexanoate $(25 \mathrm{mM})$ at pH 7 and $25^{\circ} \mathrm{C}$. Experiments were performed as described in Section 2.7. The activity is given in $\mu$ moles of substrate hydrolyzed per minute and mg of immobilized enzyme. *Activity $\left(\times 10^{3}\right)$, **Activity $\left(\times 10^{2}\right)$

\begin{tabular}{|c|c|c|c|c|}
\hline \multirow[b]{2}{*}{ Biocatalyst } & \multicolumn{4}{|c|}{ Substrate and experimental conditions } \\
\hline & $\begin{array}{l}\text { Methyl mandelate, } \\
\text { aqueous media }\end{array}$ & $\begin{array}{l}\text { Ethyl hexanoate, } \\
\text { aqueous media }\end{array}$ & $\begin{array}{l}\text { Ethyl hexanoate, } \\
50 \% \text { ACN }\end{array}$ & $\begin{array}{l}\text { Ethyl hexanoate, } \\
90 \% \text { ACN }\end{array}$ \\
\hline OCCALB & $61.8 \pm 3.1$ & - & $708.0 \pm 35.4$ & $37.2 \pm 1.9$ \\
\hline OCGLXCALB pH 10 & $68.0 \pm 3.4$ & - & $902.2 \pm 45.1$ & $50.9 \pm 2.5$ \\
\hline OCGLXCALB pH 10 - mercaptoethanol & $65.8 \pm 3.3$ & - & $626.7 \pm 31.3$ & $46.9 \pm 2.3$ \\
\hline OCGLXLU pH 10 & $23.4 \pm 1.2^{*}$ & $13.2 \pm 0.7$ & $89.8 \pm 4.5^{*}$ & - \\
\hline OCGLXLU pH 10 - mercaptoethanol & $20.8 \pm 1.0^{*}$ & $12.5 \pm 0.6$ & $79.0 \pm 4.0^{*}$ & - \\
\hline OCRML & $22.5 \pm 1.1^{*}$ & $6.7 \pm 0.3$ & $26.2 \pm 1.3^{* *}$ & - \\
\hline OCGLXRML pH 10 & $5.9 \pm 0.3^{*}$ & $7.5 \pm 0.4$ & $55.0 \pm 2.8^{* *}$ & - \\
\hline OCGLXRML pH 10 - mercaptoethanol & $4.9 \pm 0.2^{*}$ & $7.3 \pm 0.4$ & $43.0 \pm 2.2^{* *}$ & - \\
\hline OCTLL & $8.6 \pm 0.4^{*}$ & $8.6 \pm 0.4$ & $0.2 \pm 0.02 * *$ & - \\
\hline
\end{tabular}

case of TLL, in aqueous media OC-TLL is almost 2 fold more active than the OCGLX using methyl mandelate, while it is slightly less active in the hydrolysis of ethyl hexanoate in aqueous media, but in 50\% acetonitrile the OCGLX become almost 100 fold more active than OC-TLL.

The four OCGLY biocatalysts can be reused for 5 cycles in hydrolysis in aqueous media of methyl mandelate or ethyl hexanoate without any appreciable decrease in enzyme activity (Fig. 3S $\dagger$ ).

The results show that the covalent immobilization after interfacial activation on octyl agarose of lipases produces some changes in enzyme specificity, perhaps not very significant compared to other changes reported in literature after using different immobilization protocols, ${ }^{27}$ but the most relevant effect is the retention of the activity in the presence of organic solvents, as previously shown in the enzyme which is just interfacially activated versus octyl agarose which may become desorbed in the presence of high concentrations of organic solvents.

\section{Conclusions}

The new octyl-glyoxyl supports, prepared by periodate oxidation of commercially available octyl-agarose, have shown a great potential to be used in the immobilization of lipases. The first immobilization is via interfacial activation, as showed by the release of most enzyme molecules after immobilization if boiled in SDS. That way, the advantages of the use of octyl-agarose remained: one step immobilization/purification, stabilization of the open form of the lipases. The use of an alkaline $\mathrm{pH}$ value after enzyme adsorption is required to achieve some covalent enzyme-support attachments. The enzyme molecules covalently attached usually presented a higher thermal stability, a higher stability and activity in presence of organic solvents, and the enzyme cannot contaminate the reaction media, because the covalent bonds are irreversible. This last advantage may be also considered a drawback, as this strategy converted a reversible immobilization method in an irreversible one. This avoids the reuse of the support after enzyme inactivation; but may also open the possibility to analyze the reactivation of the immobilized enzyme by unfolding/refolding strategies ${ }^{36}$ of the OCGLX immobilized lipases (studies in course in our research group).

In general, a high percentage of the lipase molecules interfacially adsorbed resulted covalently attached (with exception of TLL). This resulted in good yields in covalent enzyme immobilization being obtained after the adsorption of the enzyme on the support that facilitates the enzyme/support reaction, on a relative dense layer of aldehydes groups (considering the activation achieved and the specific area of agarose $4 \mathrm{~B}$, around 5-6 aldehyde groups $/ 1000 \mathrm{~A}^{2}$ ). However, the aldehyde residues will be under a layer of longer octyl groups, and lipases are not generally very rich in Lys residues. The previous interfacial activation of the lipases on the octyl support improves the enzyme stability, producing a lower impact of the incubation of enzymes at $\mathrm{pH}$ 10. In fact, three of the used enzymes cannot be immobilized on glyoxyl agarose, with even higher activation than the OCGLX, because of the slow immobilization rate and low stability under these conditions.

After confirming the advantages of a mixed interfacial activation/covalent immobilization, it should be convenient to elaborate strategies where $100 \%$ of the enzyme molecules interfacially activated versus the octyl support could become covalently attached. In this sense, an enrichment of the enzyme surface in new amino groups (chemically or genetically) seems a convenient strategy, and it has been assayed with success to improve the covalent attachment of some enzymes on glyoxyl supports. $^{33,37}$ This way, this new support opens new research lines to improve the results and explore the advantages that offer. Other heterofunctional supports, combining other chemical reactive moieties on the support and other causes for enzyme immobilization (e.g., ion exchange, interaction with immobilized metal chelate, thiol) are very useful for other enzymes, but they cannot guarantee the immobilization- 
stabilization of the open form of lipases as the strategy proposed in this paper. ${ }^{17}$

\section{Acknowledgements}

We gratefully recognize the support from the MINECO of Spanish Government, CTQ2013-41507-R. The predoctoral fellowships for Ms. Rueda (Colciencia, Colombian Goberment) and $\mathrm{Mr}$ dos Santos (CNPq, Brazil) are also recognized. The authors wish to thank Mr Ramiro Martínez (Novozymes, Spain) for kindly supplying the enzymes used in this research. The help and comments from Dr Ángel Berenguer (Instituto de Materiales, Universidad de Alicante) are kindly acknowledged.

\section{References}

1 P. Y. Stergiou, A. Foukis, M. Filippou, M. Koukouritaki, M. Parapouli, L. G. Theodorou, E. Hatziloukas, A. Afendra, A. Pandey and E. M. Papamichael, Biotechnol. Adv., 2013, 31, 1846-1859.

2 (a) M. Reetz, Curr. Opin. Chem. Biol., 2002, 6(2), 145; (b) F. Rantwijk, R. Lau and R. Sheldon, Trends Biotechnol., 2003, 21, 131-150; (c) P. Adlercreutz, Chem. Soc. Rev., 2013, 42, 6406-6436.

3 (a) V. Gotor-Fernández, R. Brieva and V. Gotor, J. Mol. Catal. B: Enzym., 2006, 40, 111-120; (b) T. Tan, J. Lu, K. Nie, L. Deng and F. Wang, Biotechnol. Adv., 2010, 28, 628-634; (c) A. M. Gumel, M. Annuar, T. Heidelberg and Y. Chisti, Process Biochem., 2011, 46, 2079-2090; (d) M. Kapoor and M. Gupta, Process Biochem., 2012, 47, 555-559; (e) Y. Yang, J. Zhang, D. Wu, Z. Xing, Y. Zhou, W. Shi and Q. Li, Biotechnol. Adv., 2014, 32, 642-651.

4 M. Petkara, A. Lali, P. Caimi and M. Daminati, J. Mol. Catal. B: Enzym., 2006, 39, 83-90.

5 (a) C. Mateo, J. Palomo, G. Fernandez-Lorente, J. M. Guisan and R. Fernandez-Lafuente, Enzyme Microb. Technol., 2007, 40, 1451-1463; (b) R. Fernandez-Lafuente, Enzyme Microb. Technol., 2009, 45, 405-418; (c) K. Hernandez and R. Fernandez-Lafuente, Enzyme Microb. Technol., 2011, 48, 107-122; (d) R. Rodrigues, C. Ortiz, A. Berenguer-Murcia, R. Torres and R. Fernández-Lafuente, Chem. Soc. Rev., 2013, 42, 6290-6307; (e) R. A. Sheldon and S. Van Pelt, Chem. Soc. Rev., 2013, 42, 6223-6235; (f) U. Guzik, K. Hupert-Kocurek and D. Wojcieszyńska, Molecules, 2014, 19, 8995-9018.

6 (a) A. M. Brozozowski, U. Derewenda, Z. S. Derewenda, G. G. Dodson, D. M. Lawson, J. P. Turkemburg, F. Bjorkling, B. Huge-Jensen, S. S. Patkar and L. Thim, Nature, 1991, 351, 491-494; (b) U. Derewenda, A. M. Brozowski, D. M. Lawson and Z. S. Derewenda, Biochemistry, 1992, 31, 1532; (c) R. Verger, Trends Biotechnol., 1997, 15, 32-38.

7 J. Uppenberg, S. Patkar, T. Bergfors and T. J. Jones, J. Mol. Biol., 1994, 235, 790-792.

8 C. Carrasco-López, C. Godoy, B. de las Rivas, G. FernándezLorente, J. M. Palomo, J. M. Guisán, R. Fernández-
Lafuente, M. Martínez-Ripoll and J. A. Hermoso, J. Biol. Chem., 2009, 284, 4365-4372.

9 H. Van Tilbeurgh, P. Egloff, C. Martinez, N. Rugani, R. Verger and C. Cambilla, Nature, 1993, 362, 814-820.

10 (a) J. M. Palomo, M. Peñas, G. Fernández-Lorente, C. Mateo, A. Pisabarro, R. Fernández-Lafuente, et al., Biomacromolecules, 2003, 4, 204-210; (b) J. M. Palomo, M. Fuentes, G. Fernández-Lorente, C. Mateo, J. M. Guisán and R. Fernández-Lafuente, Biomacromolecules, 2003, 4, 16; (c) R. Fernandez-Lafuente, P. Armisén, P. Sabuquillo, G. Fernández-Lorente and J. M. Guisán, Chem. Phys. Lipids, 1998, 93, 185-197.

11 (a) A. Bastida, P. Sabuquillo, P. Armisen, R. FernándezLafuente, J. Huguet and J. M. Guisán, Biotechnol. Bioeng., 1998, 58, 486-493; (b) G. Fernández-Lorente, J. M. Palomo, Z. Cabrera, J. M. Guisán and R. Fernández-Lafuente, Enzyme Microb. Technol., 2007, 41, 565-569.

12 (a) M. Pregnolato, M. Terreni, I. De Fuentes, A. R. Alcantara, P. Sabuquillo, R. Fernandez-Lafuente and J. M. Guisan, J. Mol. Catal. B: Enzym., 2001, 11, 757-763; (b) G. Fernandez-Lorente, J. M. Palomo, J. Cocca, C. Mateo, P. Moro, M. Terreni, R. Fernandez-Lafuente and J. M. Guisan, Tetrahedron, 2003, 59, 5705-5711; (c) I. Nieto, S. Rocchietti, D. Ubiali, G. Speranza, C. Morelli, I. Fuentes, A. Alcantara and M. Terreni, Enzyme Microb. Technol., 2005, 37, 514-520; (d) O. Barbosa, M. Ruiz, C. Ortiz, M. Fernández, R. Torres and R. Fernandez-Lafuente, Process Biochem., 2012, 47, 867-876; (e) M. Yousefi, M. Mohammadi and Z. J. Habibi, J. Mol. Catal. B: Enzym., 2014, 104, 87-94; (f) C. Garcia-Galan, J. C. Dos Santos, O. Barbosa, R. Torres, E. Pereira, V. Cortes, L. R. B. Gonçalves and R. Fernandez-Lafuente, Process Biochem., 2014, 49, 604-616.

13 G. Fernandez-Lorente, M. Filice, D. Lopez-Vela, C. Pizarro, L. Wilson, L. Betancor, Y. Avila and J. M. Guisan, J. Am. Oil Chem. Soc., 2011, 88, 801-807.

14 G. Fernandez-Lorente, J. M. Palomo, Z. Cabrera, R. Fernandez-Lafuente and J. M. Guisán, Biotechnol. Bioeng., 2007, 97, 242-250.

15 C. Garcia-Galan, A. Berenguer-Murcia, R. FernandezLafuente and R. C. Rodrigues, Adv. Synth. Catal., 2011, 353, 2885-2904.

16 O. Barbosa, R. Torres, C. Ortiz and R. Fernandez-Lafuente, Process Biochem., 2012, 47, 766.

17 O. Barbosa, R. Torres, C. Ortiz, A. Berenguer-Murcia, R. C. Rodrigues and R. Fernandez-Lafuente, Biomacromolecules, 2013, 14, 2433-2462.

18 C. Bernal, A. Illanes and L. Wilson, Langmuir, 2014, 30, 35573566.

19 (a) J. M. Guisán, Enzyme Microb. Technol., 1988, 10, 375-382; (b) C. Mateo, J. M. Palomo, M. Fuentes, L. Betancor, V. Grazu, F. López-Gallego, B. C. C. Pessela, A. Hidalgo, G. FernándezLorente, R. Fernández-Lafuente and J. M. Guisán, Enzyme Microb. Technol., 2006, 39, 274-280.

20 (a) C. Mateo, O. Abian, M. Bernedo, E. Cuenca, M. Fuentes, G. Fernandez-Lorente, J. M. Palomo, V. Grazu, B. C. C. Pessela, C. Giacomini, G. Irazoqui, A. Villarino, 
K. Ovsejevi, F. Batista-Viera, R. Fernandez-Lafuente and J. M. Guisán, Enzyme Microb. Technol., 2005, 37, 456-462; (b) V. Grazu, L. Betancor, T. Montes, F. Lopez-Gallego, J. M. Guisan and R. Fernandez-Lafuente, Enzyme Microb. Technol., 2006, 38, 960-966.

21 (a) R. M. Blanco, J. J. Calvete and J. M. Guisan, Enzyme Microb. Technol., 1989, 11, 353-359; (b) R. C. Rodrigues, A. Berenguer-Murcia and R. Fernandez-Lafuente, $A d v$. Synth. Catal., 2011, 353, 2216-2238.

22 O. Kirk and M. W. Christensen, Org. Process Res. Dev., 2002, 6, 446-451.

23 J. Uppenberg, M. T. Hansen, S. Patkar and T. A. Jones, Structure, 1994, 2, 293-308.

24 R. Fernandez-Lafuente, J. Mol. Catal. B: Enzym., 2010, 62, 197-212.

25 (a) R. C. Rodrigues and R. Fernandez-Lafuente, J. Mol. Catal. B: Enzym., 2010, 64, 1-22; (b) R. C. Rodrigues and R. Fernandez-Lafuente, J. Mol. Catal. B: Enzym., 2010, 66, 15-32.

26 L. de Maria, J. Vind, K. M. Oxenbøll, A. Svendsen and S. Patkar, Appl. Microbiol. Biotechnol., 2007, 74, 290-300.

27 (a) R. C. Rodrigues, C. Ortiz, A. Berenguer-Murcia, R. Torres and R. Fernández-Lafuente, Chem. Soc. Rev., 2013, 42, 62906307; (b) C. Garcia-Galan, A. Berenguer-Murcia, R. Fernandez-Lafuente and R. C. Rodrigues, Adv. Synth. Catal., 2011, 353, 2885-2904; (c) C. Mateo, J. M. Palomo, G. Fernandez-Lorente, J. M. Guisan and R. FernandezLafuente, Enzyme Microb. Technol., 2007, 40, 1451-1463.

28 M. M. Bradfords, Anal. Biochem., 1976, 72, 248-254.

29 T. P. Nevell, Oxidation, Methods in Carbohydrate Chemistry, 1963, vol. 3 .

30 U. K. Laemmli, Nature, 1970, 227, 680-685.
31 R. Fernandez-Lafuente, C. M. Rosell, V. Rodriguez, C. Santana, G. Soler, A. Bastida and J. M. Guisan, Enzyme Microb. Technol., 1993, 15, 546-550.

32 J. Pedroche, M. Del Mar, C. Mateo, R. Fernández-Lafuente, J. Girón-Calle, M. Alaiz, J. Vioque, J. M. Guisán and F. Millán, Enzyme Microb. Technol., 2007, 40, 1160-1166.

33 R. C. Rodrigues, C. A. Godoy, G. Volpato, M. A. Z. Ayub, R. Fernandez-Lafuente and J. M. Guisan, Process Biochem., 2009, 44, 963-968.

34 J. M. Bolivar, C. Mateo, C. Godoy, B. C. C. Pessela, D. S. Rodrigues, R. L. C. Giordano, R. Fernandez-Lafuente and J. M. Guisan, Process Biochem., 2009, 44, 757-763.

35 J. M. Bolivar, F. López-Gallego, C. Godoy, D. S. Rodrigues, R. C. Rodrigues, P. Batalla, J. Rocha-Martín, C. Mateo, R. L. C. Giordano and J. M. Guisán, Enzyme Microb. Technol., 2009, 45, 477-483.

36 (a) R. C. Rodrigues, J. M. Bolivar, A. Palau-Ors, G. Volpato, M. A. Z. Ayub, R. Fernandez-Lafuente and J. M. Guisan, Enzyme Microb. Technol., 2009, 44, 386-393; (b) R. C. Rodrigues, C. A. Godoy, M. Filice, J. M. Bolivar, A. Palau-Ors, J. M. Garcia-Vargas, O. Romero, L. Wilson, M. A. Z. Ayub, R. Fernandez-Lafuente and J. M. Guisan, Process Biochem., 2009, 44, 641-646.

37 (a) O. Abian, V. Grazú, J. Hermoso, R. González, J. L. García, R. Fernández-Lafuente and J. M. Guisán, Appl. Environ. Microbiol., 2004, 70, 1249-1251; (b) F. López-Gallego, T. Montes, M. Fuentes, N. Alonso, V. Grazu, L. Betancor, J. M. Guisán and R. Fernández-Lafuente, J. Biotechnol., 2005, 116, 1-10; (c) G. Fernandez-Lorente, C. A. Godoy, A. A. Mendes, F. Lopez-Gallego, V. Grazu, B. de las Rivas, J. M. Palomo, J. Hermoso, R. Fernandez-Lafuente and J. M. Guisan, Biomacromolecules, 2008, 9, 2553-2561. 